Article

\title{
Effects on Rotational Dynamics of Azo and Hydrazodicarboxamide-Based Rotaxanes ${ }^{\dagger}$
}

\author{
Adrian Saura-Sanmartin, Juan S. Martinez-Espin, Alberto Martinez-Cuezva *, \\ Mateo Alajarin and Jose Berna* \\ Departamento de Química Orgánica, Facultad de Química, Regional Campus of International Excellence \\ “Campus Mare Nostrum”, Universidad de Murcia, 30100 Murcia, Spain; adrian.saura@um.es (A.S.-S.); \\ j.s.m.espin@smn.uio.no (J.S.M.-E.); alajarin@um.es (M.A.) \\ * Correspondence: amcuezva@um.es (A.M.-C.); ppberna@um.es (J.B.); Tel.: +34-868-88-7498 (J.B.) \\ + Initial data presented at the 20th International Electronic Conference on Synthetic Organic Chemistry, \\ ECSOC-20, https:/ / sciforum.net/conference/ecsoc-20/paper/3554, 1-30 November 2016, paper d003.
}

Received: 1 June 2017; Accepted: 26 June 2017; Published: 28 June 2017

\begin{abstract}
The synthesis of novel hydrogen-bonded [2]rotaxanes having two pyridine rings in the macrocycle and azo- and hydrazodicarboxamide-based templates decorated with four cyclohexyl groups is described. The different affinity of the binding sites for the benzylic amide macrocycle and the formation of programmed non-covalent interactions between the interlocked components have an important effect on the dynamic behavior of these compounds. Having this in mind, the chemical interconversion between the azo and hydrazo forms of the [2] rotaxane was investigated to provide a chemically-driven interlocked system enable to switch its circumrotation rate as a function of the oxidation level of the binding site. Different structural modifications were carried out to further functionalize the nitrogen of the pyridine rings, including oxidation, alkylation or protonation reactions, affording interlocked azo-derivatives whose rotation dynamics were also analyzed.
\end{abstract}

Keywords: template synthesis; hydrogen bonded rotaxanes; pirouetting motion; NMR studies

\section{Introduction}

Mechanically interlocked compounds are chemical entities composed by, at least two or more entwined components [1-3]. The lacking of a covalent bond between the subunits of these compounds allows relative large amplitude motions, such as translation, rotation (pirouetting) or rocking (Figure 1) [4,5]. During the last decades, the control of the internal dynamics of these species under different external stimuli allowed the development of smart interlocked devices for a broad range of applications [6-12].
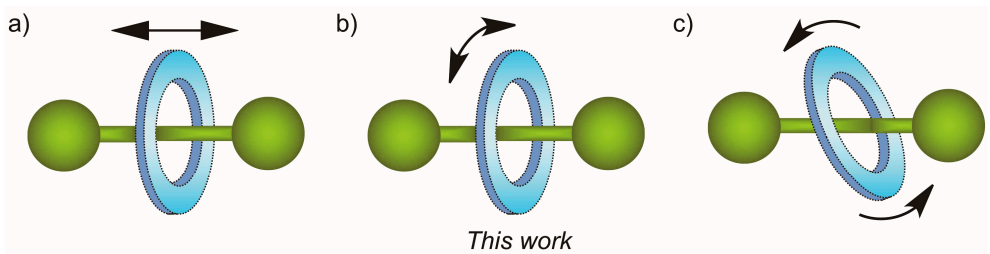

Figure 1. Schematic representation of the most common molecular motions in [2]rotaxanes: (a) translation; (b) rotation or pirouetting; and (c) rocking.

The synthesis of hydrogen-bonded rotaxanes requires the presence of suitable binding sites able to template the formation of the corresponding tetralactam macrocycle. In this sense, the employment of 1,4-dicarboxamides [13-15], nitrones [16,17], squaraines [18,19] or di(acylamino)pyrididines [20-23], 
together with hydrogen-bonding templation with anions [24,25] can be highlighted. In this arena, some of us reported that azodicarboxamides are able to act as effective templates for driving the assembly of hydrogen-bond-assembled [2]rotaxanes [26-28]. Moreover, these binding sites can be efficiently interconverted with their reduced hydrazo forms through hydrogenation-dehydrogenation of its nitrogen-nitrogen bond. This type of chemical control was efficiently employed for building stimuli-responsive molecular shuttles [26]. In a different work, the rotation dynamics of these particular systems were shown to depend on the oxidation level of the nitrogen-based binding site [27].

In polyamide-based rotaxanes, the thread-macrocycle affinity can be modulated by the variation of the substituents on the macrocyclic counterpart. Indeed, the presence of electron-donor or electron-withdrawing groups can strengthen or weaken this interaction, breaking or accelerating the rotational motion of the ring $[29,30]$. In pyridine-containing macrocycles a chemical variation of the pyridyl nitrogen can also undergo changes on the rotational speed [31].

Herein we describe the effect of integrating dicyclohexylmethyl stoppers on an azodicarboxamide template in the preparation of a hydrogen-bond-assembled [2]rotaxane having two pyridine rings into the macrocycle and its interconversion into its corresponding hydrazo surrogate. In addition, some chemical modifications of the pyridine moiety were also achieved, including protonation, oxidation and alkylation reactions for providing a novel set of azodicarboxamide-based rotaxanes. Finally the rotational dynamics of each interlocked molecule was studied by temperature-dependent NMR experiments.

\section{Results}

\subsection{Synthesis of Threads [2H]-2 and $\mathbf{2}$}

The reaction of diphenyl hydrazodicarboxylate (1) with bis(cyclohexylmethyl) amine in the presence of two equivalents of triethylamine provided the hydrazodicarboxamide $[2 \mathrm{H}]-2$ in a $51 \%$ yield. Next, the oxidation of the hydrazo compound [2H]-2 was carried out using $\mathrm{N}$-bromosuccinimide in the presence of pyridine. This reaction was monitored by IR spectroscopy observing the vanishing of the band ascribed to the $\mathrm{NH}$ at $3397 \mathrm{~cm}^{-1}$ of the hydrazo compound and the shifting of the absorption frequency of the CO band from $1653 \mathrm{~cm}^{-1}$ to $1699 \mathrm{~cm}^{-1}$. After the work-up, the azodicarboxamide 2 was isolated in a $97 \%$ yield (Scheme 1).<smiles>CC#CC(=O)OC(=O)NNC(=O)Oc1ccccc1</smiles>

Scheme 1. Synthesis of the hydrazodicarboxamide [2H]-2 and its azo derivative 2. Reagents and conditions: (i) $\left(\mathrm{CyCH}_{2}\right)_{2} \mathrm{NH}, \mathrm{Et}_{3} \mathrm{~N}, \mathrm{CHCl}_{3}$, reflux, $24 \mathrm{~h}, 51 \%$; (ii) NBS (N-bromosuccinimide), pyridine, $\mathrm{CH}_{2} \mathrm{Cl}_{2}, 25^{\circ} \mathrm{C}, 1 \mathrm{~h}, 97 \%$. (Cy = cyclohexyl, $\mathrm{C}_{6} \mathrm{H}_{11}$ ).

\subsection{Synthesis of Rotaxanes [2H]-3 and $\mathbf{3}$}

The five-component clipping reaction between $p$-xylylenediamine, 3,5-pyridinedicarbonyl dichloride, the hydrazo template $[2 \mathrm{H}]-2$ and triethylamine provided the hydrazo[2]rotaxane $[2 \mathrm{H}]-3$ in only $4 \%$ yield (Scheme 2). The rotaxane formation reaction using the template 2 leads to the interlocked azo compound 3 in a more reasonable 10\% yield thus probing the better templating capability of the azo compound for driving the construction of the tetralactam ring around the thread (Scheme 2). 


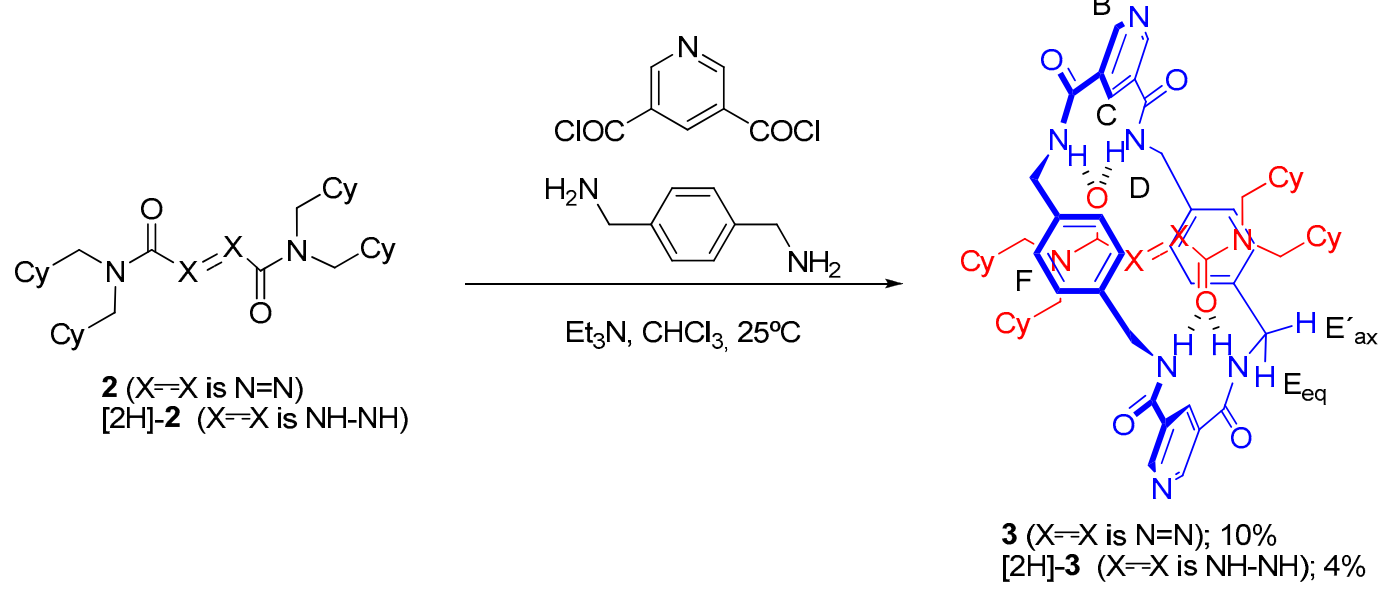

Scheme 2. Syntheses of the azo and hydrazo rotaxanes 3 and $[2 \mathrm{H}]-3$. Reagents and conditions: p-xylylenediamine, 3,5-pyridinedicarbonyl dichloride, $\mathrm{Et}_{3} \mathrm{~N}, \mathrm{CHCl}_{3}, 25^{\circ} \mathrm{C}, 4 \mathrm{~h}$.

These results are in line with those obtained for the assembly of $N, N, N^{\prime}, N^{\prime}$-tetrabenzylhydrazodicarboxamide and its corresponding azo derivative [26]. The hydrazodicarboxamide threads likely adopt a ground state conformation in which the carbonyl hydrogen bond acceptors do not have the ideal orientation of an efficient template [32]. However, the incorporation of two pyridine rings into the tetralactam ring also provokes a noticeable decrease of the yield probably due to a non-ideal aggregation between the thread and the intermediate polyamides, precursors of the interlocked tetralactam [29].

\subsection{Analysis of Threads $\mathbf{2}$ and Rotaxanes $\mathbf{3}$}

Figure 2 displays the stacked plot of the ${ }^{1} \mathrm{H}-\mathrm{NMR}$ spectrum of each thread $[2 \mathrm{H}]-\mathbf{2}$ and 2 and the corresponding interlocked compounds $[2 \mathrm{H}]-3$ and 3 . Both comparisons prove the interlocked nature of the assembled products. Nevertheless, the shape of the signal of the macrocyclic methylenic protons $\mathrm{H}_{\mathrm{E}}$ of these rotaxanes deserves to be highlighted. Whereas the signals ascribed to the macrocyclic methylene protons of [2H]-3 (Figure 2b) appears as a slightly broad singlet a $4.56 \mathrm{ppm}$, the analogue signals of 3 (Figure $2 \mathrm{~d}$ ) are non-equivalent as result of the different magnetic environments attributed to its equatorial $\left(\mathrm{H}_{\mathrm{E}}\right)$ and axial $\left(\mathrm{H}_{\mathrm{E}}{ }^{\prime}\right)$ positions in the macrocycle. The peak for the equatorial methylene proton emerges as a doublet of doublets $\left({ }^{2} J_{(\mathrm{H} 1, \mathrm{H} 2)}=14.3 \mathrm{~Hz}\right.$ and $\left.{ }^{3} J_{(\mathrm{H} 1, \mathrm{HD})}=7.3 \mathrm{~Hz}\right)$ at $4.96 \mathrm{ppm}$ and the peak for the axial one appears as a doublet $\left(J_{(\mathrm{H} 1, \mathrm{H} 2)}=14.1 \mathrm{~Hz}\right)$ at $4.06 \mathrm{ppm}$. This patent difference is connected with the rotational motion of the ring of single binding site amide-based [2]rotaxanes [16,17,29-31,33-37] which occurs at a higher spinning rate in [2H]-3 than in 3 . As usually occurred in polyamide-based rotaxanes, peaks corresponding to the hydrogens of the thread are shifted to lower ppm values due to the presence of the macrocycle around it. Interestingly, the set of signals referred to the hydrogens $\mathrm{H}_{\mathrm{b}}$ and $\mathrm{H}_{\mathrm{b}}{ }^{\prime}$ in thread 2, which indicates a slow rotation motion of the amide $\mathrm{CO}-\mathrm{N}$ bond, emerges in only one signal in 3 after rotaxane formation. Moreover, the substantial upfield shift ( $\Delta \delta \approx 0.5 \mathrm{ppm}$ ) corresponding to the signal of the methylenic $\mathrm{H}_{\mathrm{d}}$ ' protons of one of the cyclohexane rings of 3 (Figure 2d) with respect to the naked thread (Figure 2c) reveals the establishment of stabilizing $\mathrm{CH} \cdots \pi$ interactions $[38,39]$ which further decelerated the rotational motion [29]. In contrast a variation of the chemical shift in about $0.25 \mathrm{ppm}$ was observed when compared thread $[2 \mathrm{H}]-2$ (Figure $2 \mathrm{a}$ ) and rotaxane $[2 \mathrm{H}]-3$ (Figure $2 \mathrm{~b}$ ) owing to the shielding effect of the aromatic rings of the macrocycle. 

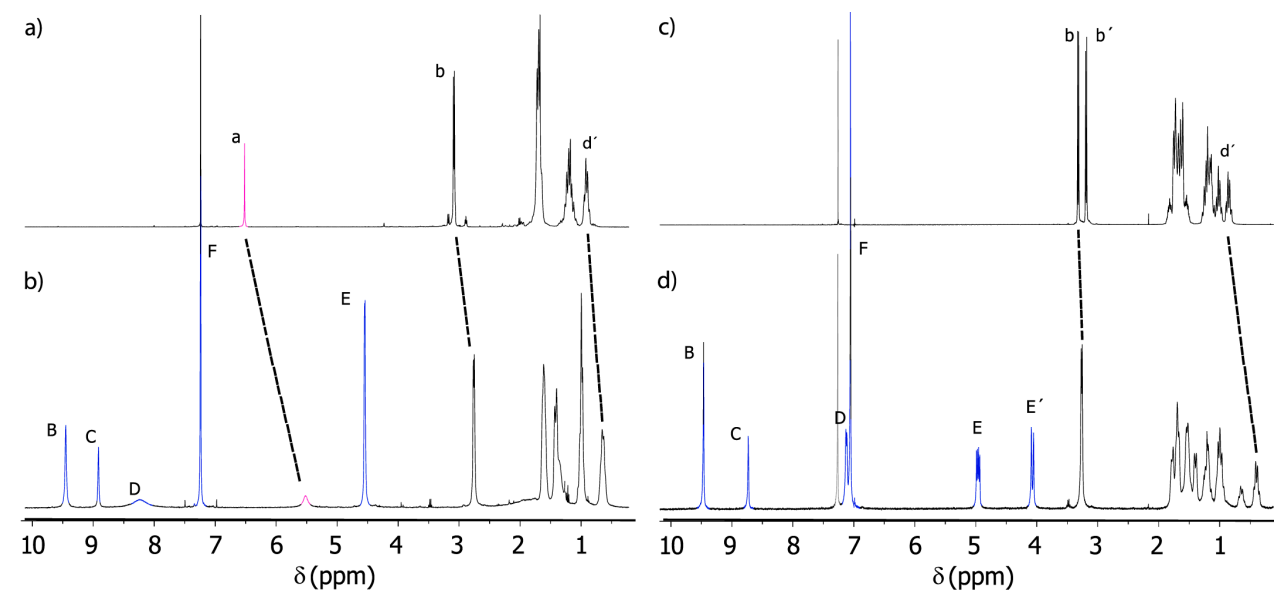

Figure 2. ${ }^{1} \mathrm{H}-\mathrm{NMR}$ spectra $\left(400 \mathrm{MHz}, \mathrm{CDCl}_{3}, 298 \mathrm{~K}\right.$ ) of (a) hydrazodicarboxamide thread [2H]-2; (b) hydrazodicarboxamide rotaxane [2H]-3; (c) azodicarboxamide thread 2; and (d) azodicarboxamide rotaxane 3. See Schemes 1 and 2 for signal assignments.

\subsection{Chemical Interconversion between Rotaxanes 3}

Taking into account the above considerations on the spinning rate of the macrocycle of the interlocked systems, most probably we could switch between two different dynamic states just by exchanging the oxidation state of the dinitrogenated binding site of these rotaxanes (for related compounds, see reference [27]). This is why we assayed the chemical interconversion between the two accessible oxidation states of [2]rotaxanes 3 . A reduction of the azo rotaxane 3 with hydrazine quantitatively afforded the [2]rotaxane [2H]-3 (Scheme 3). In the reverse sense, [2H]-3 was completely transformed by oxidation with $\mathrm{N}$-bromosuccinimide in the presence of pyridine. In this way, we switched from a fast ring rotation state of a rotaxane to a slow ring rotation one, and viceversa, by simple and efficient chemical modifications.

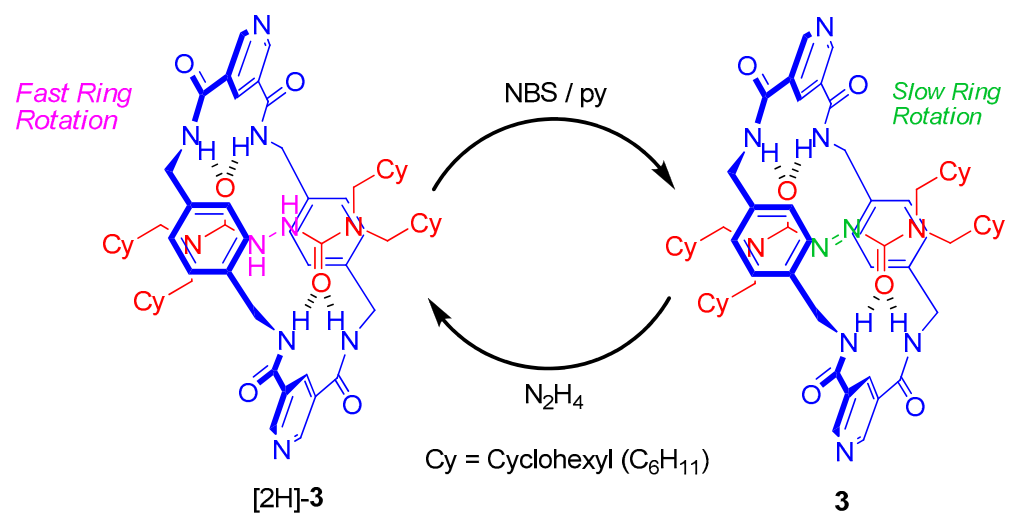

Scheme 3. Interconversion of the azo and hydrazo rotaxanes 3 and $[2 \mathrm{H}]-3$.

\subsection{Chemical Functionalization of the Pyridine Rings of the Macrocycle of Rotaxane 3}

We next evaluated the changes on the pirouetting motion of the macrocycle following some modifications at the pyridinic nitrogen atom. We envisaged that this could modify the affinity of the macrocycle for the azo-based binding site and, consequently, its rotational dynamics. Following this idea we synthesized the azo-derived rotaxane 4 from compound 3 , in which the two nitrogen atoms of the pyridine rings were chemically converted into $\mathrm{N}$-oxides by reaction with $m$-chloroperbenzoic acid ( $m$-CPBA) (Scheme 4). The reaction proceeded smoothly at room temperature obtaining a high yield of the corresponding $N$-oxide derivative 4 . 


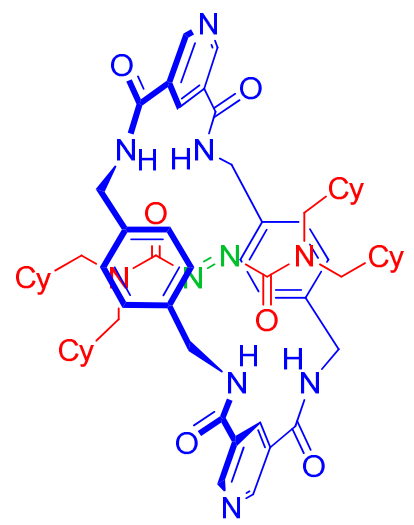

3

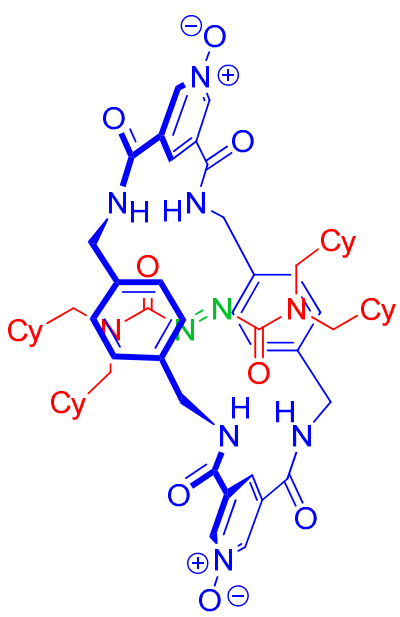

4

Scheme 4. Synthesis of the azodicarboxamide-based rotaxane 4. Reagents and conditions: $m$-CPBA (3 equiv.), $\mathrm{CHCl}_{3}, 25^{\circ} \mathrm{C}, 3 \mathrm{~h}$.

Due to the inherent basicity of the pyridine moiety, the corresponding pyridinium trifluoacetate salt 5 can be easily prepared by treatment of rotaxane 3 with an excess of trifluoacetic acid (Scheme 5). We expected that the double protonation of the tetralactam macrocycle can induce an acceleration of the pirouetting motion around the thread as happened in other fumaramide-based rotaxanes [31]. The corresponding salt $\mathbf{5}$ was obtained in quantitative yield after complete evaporation of the excess of trifluoroacetic acid under high vacuum. Additionally, the initial compound 3 was easily recovered by deprotonation with the weakly basic resin Amberlyst ${ }^{\circledR}$ A21.

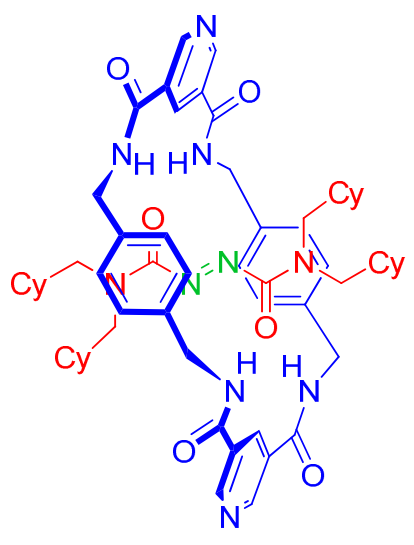

3

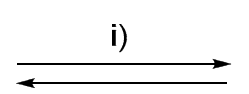

ii)

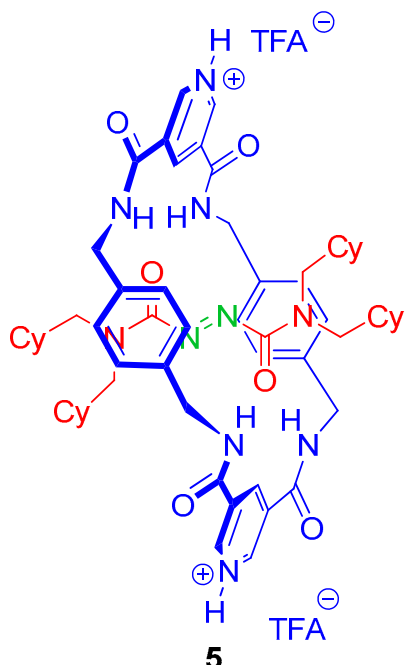

Scheme 5. Synthesis of the TFA salt azodicarboxamide-based rotaxane 5. Reagents and conditions: (i) trifluoroacetic acid, $\mathrm{CH}_{3} \mathrm{Cl}, 25^{\circ} \mathrm{C}, 1 \mathrm{~h}$; (ii) Amberlyst ${ }^{\circledR} \mathrm{A} 21, \mathrm{CH}_{3} \mathrm{Cl}, 25^{\circ} \mathrm{C}, 1 \mathrm{~h}$.

Another modification that can be achieved over the pyridine moiety is the $\mathrm{N}$-alkylation with different aliphatic electrophiles, such as alkyl halides. Indeed, the reaction between rotaxane 3 and allyl iodide provided the corresponding rotaxane 6 in high yield, which was insoluble in chlorinated solvents (Scheme 6). A counteranion exchanged $\left(\mathrm{SbF}_{6}{ }^{-}\right.$and $\mathrm{PF}_{6}{ }^{-}$) was tested to improve the solubility of the system, but these attempts were fruitless. 


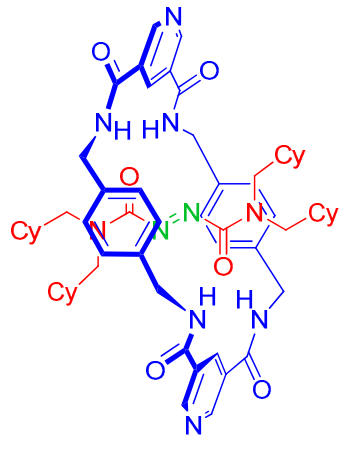

3

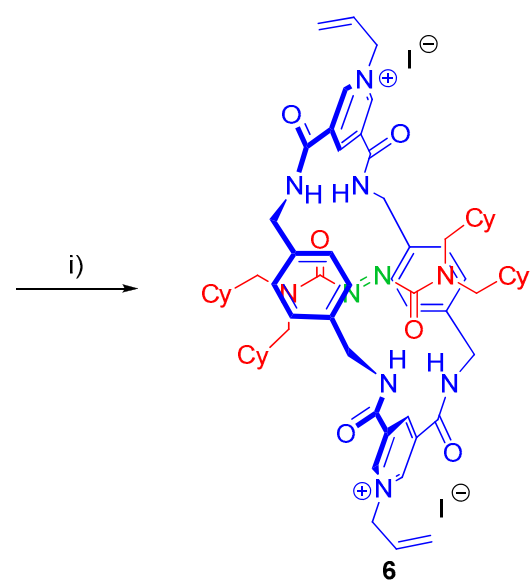

6

Scheme 6. Synthesis of the azodicarboxamide-based rotaxane 6. Reagents and conditions: (i) allyl iodide (3 equiv.), $\mathrm{CH}_{3} \mathrm{CN}, 80^{\circ} \mathrm{C}, 48 \mathrm{~h}$.

\subsection{Variable-Temperature ${ }^{1} H-N M R$ Experiments: Calculation of the Rotational Barrier}

The estimation of the ring affinity towards the binding sites in interlocked molecular shuttles is crucial for a correct control of their internal translational motion. In benzylic amide [2]rotaxanes, the energy barrier for the rotation of the macrocycle around the template is directly correlated to their affinity [16,29-31,33-35]. Having this in mind, we decided to calculate the energy barrier of rotation of the pyridine-based tetralactam ring in the synthesized rotaxanes 3 and $[2 \mathrm{H}]-3$, and in their corresponding derivatives $\mathbf{4} \mathbf{- 5}$ by variable-temperature (VT) NMR experiments (see Supporting Information). Note that if the interactions between the macrocycle and thread are weak enough a fast exchange between the methylene protons $\left(\mathrm{H}_{\mathrm{E}}\right)$ of the macrocycle should be observed. The rate of this process would decrease at lower temperatures, resulting in the splitting of the singlet corresponding to the hydrogens located in axial $\left(\mathrm{H}_{\mathrm{Eax}}\right)$ and equatorial $\left(\mathrm{H}_{\mathrm{E}^{\prime} \mathrm{eq}}\right)$ positions in the ${ }^{1} \mathrm{H}-\mathrm{NMR}$ spectrum.

The rate of rotation of $[2 \mathrm{H}]-3$ is higher than the one of the azo-derivative 3 , indicating a lower level of interaction between the reduced thread and the macrocycle, and thus a faster ring rotation (Table 1, entries 1-2). This is fully consistent with the reported data in related azo- and hydrazo-based rotaxanes $[26,28]$. Thus, the energy barrier in $[2 \mathrm{H}]-3\left(10.7 \mathrm{kcal} \cdot \mathrm{mol}^{-1}\right)$ is very similar to the calculated one in the previously reported rotaxane $[2 \mathrm{H}]-7\left(10.4 \mathrm{kcal} \cdot \mathrm{mol}^{-1}\right)$, bearing four tetrabenzyl groups as stoppers and the classic macrocyclic component (Figure 3) (Table 1, entries 1 and 5). On the other hand, when comparing the energy barrier values of rotaxanes $3\left(19.1 \mathrm{kcal} \cdot \mathrm{mol}^{-1}\right)$ and $7\left(14.8 \mathrm{kcal} \cdot \mathrm{mol}^{-1}\right)$ a huge effect on the dynamics is observed due mainly to the presence of different stoppers (Table 1, entries 2 and 6). The higher energy barrier in rotaxane 3 can be explained by the establishment of cooperative $\mathrm{CH} \cdots \pi$ interactions between the macrocycle and the cyclohexyl stoppers [29], in combination with the increase of the steric hindrance of the non-planar cyclohexyl groups compared with the planar phenyl rings, which slow down the spinning rate of the macrocycle. It should be note that dissimilar ring affinity of the azo and hydrazo binding sites in the rotaxane 3 and $[2 \mathrm{H}]-3\left(8.4 \mathrm{kcal} \cdot \mathrm{mol}^{-1}\right)$ is one of the highest energy gaps reported for switchable binding sites. The oxidation of the pyridine rings to the corresponding $\mathrm{N}$-oxide makes the macrocycle in compound 4 to rotate slightly faster when compared with the ring of the starting azo-based rotaxane 3 (Table 1, entries 2-3). Whereas the macrocycle in the trifluoroacetate salt 5 rotates at nearly the same rate than in the neutral compound, in contrast with the reported data in related hydrogen-bonded rotaxanes [31]. Unfortunately, in the case of the allyl-dipyridinium derivative 6 we were not able to perform VT NMR experiments due to its poor solubility in chlorinated solvents $\left(\mathrm{CDCl}_{3}\right.$ or $\left.\mathrm{C}_{2} \mathrm{D}_{2} \mathrm{Cl}_{4}\right)$. 
Table 1. Kinetic and thermodynamic parameters for macrocycle pirouetting obtained from variable-temperature ${ }^{1} \mathrm{H}$ NMR spectra of the [2]rotaxanes in deuterated solvents. $\Delta v$ is the separation, in $\mathrm{Hz}$, between the resonance peaks of axial $\left(\mathrm{H}_{\mathrm{Eax}}\right)$ and equatorial $\left(\mathrm{H}_{\mathrm{E}^{\prime} \mathrm{eq}}\right)$ benzylic hydrogens at low temperature, $\mathrm{k}_{\mathrm{c}}$ is the rate exchange in $\mathrm{s}^{-1}$ and $\mathrm{T}_{\mathrm{c}}$ is the coalescence temperature in $\mathrm{K} . \Delta \mathrm{G}^{\neq}$is the energy barrier (free energy of activation) of the ring rotation process (see Supplementary Materials).

\begin{tabular}{ccccccc}
\hline Entry & Rotaxane & $\delta\left(\mathbf{H}_{\text {Eeq }}\right) ; \delta\left(\mathbf{H}_{\mathrm{E}^{\prime} \mathbf{a x}}\right) \mathbf{p p m}$ & $\boldsymbol{\Delta v} / \mathbf{H z}$ & $\mathbf{k}_{\mathrm{c}} / \mathbf{s}^{-\mathbf{1}}$ & $\mathbf{T}_{\mathbf{c}} \mathbf{1} / \mathbf{K}$ & $\Delta \mathbf{G}^{\neq 2} /{\mathbf{k c a l ~} \mathbf{~ m o l}^{-\mathbf{1}}}$ \\
\hline 1 & {$[2 \mathrm{H}]-\mathbf{3}$} & $4.64 ; 4.33$ & 128 & 290 & 228 & 10.7 \\
2 & $\mathbf{3}$ & $4.96 ; 4.06$ & 360 & 802 & 413 & 19.1 \\
3 & $\mathbf{4}$ & $4.98 ; 4.00$ & 392 & 873 & 408 & 18.6 \\
4 & $\mathbf{5}$ & $4.96 ; 4.07$ & 356 & 793 & 413 & 19.0 \\
5 & {$[2 \mathrm{H}]-\mathbf{7}^{3}$} & $4.78 ; 4.22$ & 237 & 527 & 228 & 10.4 \\
6 & $\mathbf{7}^{3}$ & $5.14 ; 3.67$ & 560 & 1245 & 333 & 14.8 \\
\hline
\end{tabular}

${ }_{1}^{1}$ NMR temperature calibration was performed using pure methanol (low temperature) or ethylene glycol (high temperature) samples; ${ }^{2}$ Value $\pm 0.2{ }^{3}$ Values reported in ref. [27].
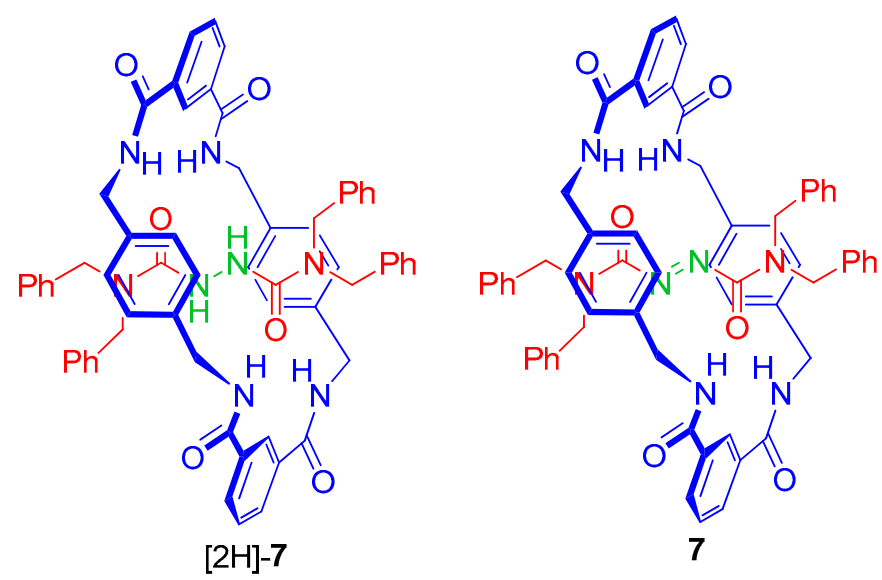

Figure 3. Tetrabenzyl-substituted hydrazo- and azo-derived rotaxanes [2H]-7 and 7 [27].

\section{Materials and Methods}

\subsection{General Information}

Unless stated otherwise, all reagents were purchased from Aldrich Chemicals (St. Louis, MO, USA) and used without further purification. HPLC grade solvents (Scharlab, Barcelona, Spain) were nitrogen saturated and were dried and deoxygenated using a Pure-Solv 400 Solvent Purification System (Innovative Technology Inc., Amesbury, MA, USA). Column chromatography was carried out using silica gel $(60 \AA, 70-200 \mu \mathrm{m}$, SDS) as stationary phase, and TLC was performed on precoated silica gel on aluminun cards $(0.25 \mathrm{~mm}$ thick, with fluorescent indicator $254 \mathrm{~nm}$, Fluka Chemie AG, Buchs, Switzerland) and observed under UV light. All melting points were determined on a Kofler hot-plate melting point apparatus and are uncorrected. ${ }^{1} \mathrm{H}-,{ }^{19} \mathrm{~F}$ - and ${ }^{13} \mathrm{C}-\mathrm{NMR}$ spectra were recorded at $298 \mathrm{~K}$ on Avance 300 and $400 \mathrm{MHz}$ instruments (Bruker, Karlsruhe, Germany). ${ }^{1} \mathrm{H}-\mathrm{NMR}$ chemical shifts are reported relative to $\mathrm{Me}_{4} \mathrm{Si}$ and were referenced via residual proton resonances of the corresponding deuterated solvent whereas ${ }^{13} \mathrm{C}-\mathrm{NMR}$ spectra are reported relative to $\mathrm{Me}_{4} \mathrm{Si}$ using the carbon signals of the deuterated solvent. Signals in the ${ }^{1} \mathrm{H}$ and ${ }^{13} \mathrm{C}$ NMR spectra of the synthesized compounds were assigned with the aid of DEPT, APT, or two-dimensional NMR experiments (COSY, HMQC and $\mathrm{HMBC}$ ). Abbreviations of coupling patterns are as follows: br, broad; s, singlet; $d$, doublet; $t$, triplet; q, quadruplet; $\mathrm{m}$, multiplet. Coupling constants (J) are expressed in Hz. High-resolution mass spectra (HRMS) were obtained using a time-of-flight (TOF) instrument (Agilent 6220, Agilent Technologies Inc., Santa Clara, CA, USA) equipped with electrospray ionization (ESI). IR spectra were registered on a Nicolet Avatar 360 FTIR spectrophotometer (Thermo Electron Corporation, Madison, WI, USA). 


\subsection{Synthesis of Threads}

\subsubsection{Synthesis of $N^{1}, N^{1}, N^{2}, N^{2}$-Tetrakis(Cyclohexylmethyl)-1,2-Hydrazodicarboxamide ([2H]-2)}

To a solution of diphenyl hydrazodicarboxylate $(\mathbf{1})(1.65 \mathrm{~g}, 6.06 \mathrm{mmol})$ in chloroform $(50 \mathrm{~mL})$ was added bis(cyclohexylmethyl)amine $(2.80 \mathrm{~g}, 13.37 \mathrm{mmol})$ followed by triethylamine $(1.69 \mathrm{~mL}$, $12.16 \mathrm{mmol})$. The reaction mixture was stirred for 15 hours at reflux temperature after which time the reaction was concentrated under reduced pressure and purified by column chromatography on silica gel using a $\mathrm{CHCl}_{3} / \mathrm{MeOH}(99 / 1)$ mixture as eluent to give the title product as a white solid ([2H]-2, 1.53 g, 51\%). m.p. = 249-251 ${ }^{\circ} \mathrm{C}$. IR (Nujol): 3627 (w), $3575(w), 3397(w), 3019(w), 2925(w)$, 1653 (w), 1449 (w), 1215 (vs), 1046 (w), 758 (vs), 699 (s). ${ }^{1} \mathrm{H}-\mathrm{NMR}\left(400 \mathrm{MHz}, \mathrm{CDCl}_{3}\right.$ ) 8: 6.54 (s, 2H, NH), $3.09\left(\mathrm{~d}, J=6.9 \mathrm{~Hz}, 8 \mathrm{H}, \mathrm{NCH}_{2}\right), 1.82-1.53\left(\mathrm{~m}, 24 \mathrm{H}, \mathrm{H}_{\mathrm{Cy}}\right), 1.34-1.05\left(\mathrm{~m}, 12 \mathrm{H}, \mathrm{H}_{\mathrm{Cy}}\right), 1.02-0.75\left(\mathrm{~m}, 8 \mathrm{H}, \mathrm{H}_{\mathrm{Cy}}\right)$. ${ }^{13} \mathrm{C}-\mathrm{NMR}\left(75 \mathrm{MHz}, \mathrm{CDCl}_{3}\right)$ 8: $159.2(\mathrm{CO}), 54.5\left(\mathrm{CH}_{2}\right), 36.9(\mathrm{CH}), 31.1,26.6,26.0$; HRMS (ESI) calcd. for $\mathrm{C}_{30} \mathrm{H}_{55} \mathrm{~N}_{4} \mathrm{O}_{2}[\mathrm{M}+\mathrm{H}]^{+}$503.4325, found 503.4329.

\subsubsection{Synthesis of $N^{1}, N^{1}, N^{2}, N^{2}$-Tetrakis(cyclohexylmethyl)-1,2-azodicarboxamide (2)}

To a solution of the 1,2-hydrazodicarboxamide [2H]-2 $(2.87 \mathrm{~g}, 5.71 \mathrm{mmol})$ in dichloromethane $(50 \mathrm{~mL})$ were added pyridine $(0.6 \mathrm{~mL}, 6.85 \mathrm{mmol})$ and $\mathrm{N}$-bromosuccinimide $(1.12 \mathrm{~g}, 6.28 \mathrm{mmol})$. The resulting orange solution was stirred at room temperature for $1 \mathrm{~h}$. Then the reaction mixture was diluted with dichloromethane $(100 \mathrm{~mL})$ and sequentially washed with water $(100 \mathrm{~mL}), 5 \%$ aqueous solution of $\mathrm{Na}_{2} \mathrm{~S}_{2} \mathrm{O}_{3}(75 \mathrm{~mL})$ and saturated solution of $\mathrm{NaHCO}_{3}(2 \times 75 \mathrm{~mL})$. The organic phase was dried with anhydrous $\mathrm{MgSO}_{4}$, and concentrated under reduced pressure to afford a crude material which was purified by column chromatography on silica gel eluting with a $\mathrm{CHCl}_{3} / \mathrm{MeOH}(98 / 2)$ mixture as eluent to give the title product as an orange solid $(2,2.77 \mathrm{~g}, 97 \%)$. m.p. $=187-189{ }^{\circ} \mathrm{C}$. IR (Nujol): 3019 (m), 2928 (w), 1699 (m), 1450 (w), 1216 (vs), 1047 (w), 759 (vs), 699 (m). ${ }^{1}$ H-NMR $\left(400 \mathrm{MHz}, \mathrm{CDCl}_{3}\right) \delta: 3.32(\mathrm{~d}, J=7.4 \mathrm{~Hz}, 4 \mathrm{H}, \mathrm{NCH}), 3.19(\mathrm{~d}, J=7.2 \mathrm{~Hz}, 4 \mathrm{H}, \mathrm{NCH}), 1.89-1.48(\mathrm{~m}, 22 \mathrm{H}$, $\left.\mathrm{H}_{\mathrm{Cy}}\right), 1.31-0.95\left(\mathrm{~m}, 18 \mathrm{H}, \mathrm{H}_{\mathrm{Cy}}\right), 0.92-0.78\left(\mathrm{~m}, 4 \mathrm{H}, \mathrm{H}_{\mathrm{Cy}}\right) .{ }^{13} \mathrm{C}-\mathrm{NMR}\left(75 \mathrm{MHz}, \mathrm{CDCl}_{3}\right) \delta: 162.6(\mathrm{CO})$, $53.4\left(\mathrm{CH}_{2}\right), 37.3(\mathrm{CH}), 36.0(\mathrm{CH}), 30.1,30.7,26.5,26.3,26.0,25.9$; HRMS (ESI) calcd. for $\mathrm{C}_{30} \mathrm{H}_{53} \mathrm{~N}_{4} \mathrm{O}_{2}$ $[\mathrm{M}+\mathrm{H}]^{+}$501.4169, found 501.4170.

\subsection{Synthesis of Rotaxanes}

\subsubsection{General Procedure for the Preparation of [2]Rotaxanes 3 and [2H]-3}

The thread ( $1 \mathrm{mmol}), 2$ or $[2 \mathrm{H}]-2$, and $\mathrm{Et}_{3} \mathrm{~N}(3.4 \mathrm{~mL}, 24 \mathrm{mmol})$ in $\mathrm{CHCl}_{3}(250 \mathrm{~mL})$ were stirred whilst solutions of $p$-xylylenediamine $(1.63 \mathrm{~g}, 12 \mathrm{mmol})$ in $\mathrm{CHCl}_{3}(40 \mathrm{~mL})$ and 3,5-pyridinedicarbonyl dichloride $(2.45 \mathrm{~g}, 12 \mathrm{mmol})$ in $\mathrm{CHCl}_{3}(40 \mathrm{~mL})$ were simultaneously added over a period of $3.5 \mathrm{~h}$ using a motor-driven syringe pump. Afterwards the resulting suspension was filtered through a Celite pad and the solvent removed under reduced pressure. The resulting solid was subjected to column chromatography (silica gel, $\mathrm{CHCl}_{3}: \mathrm{MeOH}, 98: 2$ ) to yield unconsumed thread, [2]rotaxane and [2]catenane.

[2]rotaxane [2H]-3. 4\% yield. White solid. m.p. > $300{ }^{\circ} \mathrm{C}$. IR (Nujol): 3579 (w), 3354 (w), 3019 (s), 2921 (w), 1658 (m), 1527 (m), 1429 (w), 1215 (vs), 1045 (w), 758 (vs), 699 (s). ${ }^{1} \mathrm{H}-\mathrm{NMR}$ (400 MHz, CDCl ${ }_{3}$ )

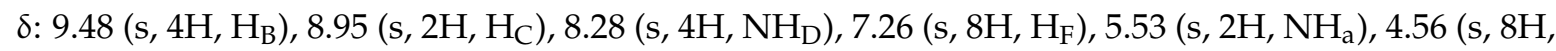
$\left.\mathrm{H}_{\mathrm{E}}\right), 2.76\left(\mathrm{~d}, J=5.7 \mathrm{~Hz}, 8 \mathrm{H}, \mathrm{H}_{\mathrm{b}}\right), 1.67-1.54\left(\mathrm{~m}, 12 \mathrm{H}, \mathrm{H}_{\mathrm{Cy}}\right), 1.46-1.31\left(\mathrm{~m}, 12 \mathrm{H}, \mathrm{H}_{\mathrm{Cy}}\right), 1.04-0.93(\mathrm{~m}, 12 \mathrm{H}$, $\left.\mathrm{H}_{\mathrm{Cy}}\right), 0.70-0.57\left(\mathrm{~m}, 4 \mathrm{H}, \mathrm{H}_{\mathrm{Cy}}\right) .{ }^{13} \mathrm{C}-\mathrm{NMR}\left(100 \mathrm{MHz}, \mathrm{CD}_{2} \mathrm{Cl}_{2}\right)$ 8: $165.2\left(\mathrm{CO}_{\text {thread }}\right), 157.8\left(\mathrm{CO}_{\text {macrocycle }}\right)$, 152.6, 137.8 (C), 131.1, 129.4, 129.1 (C), 55.1 $\left(\mathrm{CH}_{2}\right), 45.5\left(\mathrm{CH}_{2}\right), 37.1(\mathrm{CH}), 31.4,26.8,26.3$. HRMS (ESI) calcd. for $\mathrm{C}_{60} \mathrm{H}_{81} \mathrm{~N}_{10} \mathrm{O}_{6}[\mathrm{M}+\mathrm{H}]^{+}$1037.6341, found 1037.6344.

[2] rotaxane 3. 10\% yield. Orange solid. m.p. $>220^{\circ} \mathrm{C}$ (decomp.). IR (Nujol): 3385 (m), 3022 (m), 2933 (s), $2850(\mathrm{~m}), 2118(\mathrm{~m}), 1670(\mathrm{~s}), 1545(\mathrm{~m}), 1445(\mathrm{~m}), 1296(\mathrm{~m}), 1224(\mathrm{~s}), 1145(\mathrm{w}), 1121(\mathrm{w}), 765(\mathrm{vs}), 672(\mathrm{vs})$. ${ }^{1} \mathrm{H}-\mathrm{NMR}\left(400 \mathrm{MHz}, \mathrm{CDCl}_{3}\right)$ 8: $9.47\left(\mathrm{~s}, 4 \mathrm{H}, \mathrm{H}_{\mathrm{B}}\right), 8.73\left(\mathrm{~s}, 2 \mathrm{H}, \mathrm{H}_{\mathrm{C}}\right), 7.12\left(\mathrm{~d}, J=6.2 \mathrm{~Hz}, 4 \mathrm{H}, \mathrm{NH}_{\mathrm{D}}\right), 7.06(\mathrm{~s}, 8 \mathrm{H}$, 
$\left.\mathrm{CH}_{\mathrm{F}}\right), 4.96\left(\mathrm{dd}, J=14.2 \mathrm{~Hz}, J=7.3 \mathrm{~Hz}, 4 \mathrm{H}, \mathrm{H}_{\mathrm{E}}{ }^{\prime}\right), 4.06\left(\mathrm{~d}, J=14.2 \mathrm{~Hz}, 4 \mathrm{H}, \mathrm{H}_{\mathrm{E}}\right), 3.29-3.22\left(\mathrm{~m}, 8 \mathrm{H}, \mathrm{H}_{\mathrm{b}}\right)$, 1.85-1.47 (m, 22H, $\left.\mathrm{H}_{\mathrm{Cy}}\right), 1.22-1.14\left(\mathrm{~m}, 8 \mathrm{H}, \mathrm{H}_{\mathrm{Cy}}\right), 1.07-0.84\left(\mathrm{~m}, 8 \mathrm{H}, \mathrm{H}_{\mathrm{Cy}}\right), 0.71-0.59\left(\mathrm{~m}, 2 \mathrm{H}, \mathrm{H}_{\mathrm{Cy}}\right)$, 0.47-0.30 (m, 4H, $\left.\mathrm{H}_{\mathrm{Cy}}\right) .{ }^{13} \mathrm{C}-\mathrm{NMR}\left(75 \mathrm{MHz}, \mathrm{CDCl}_{3}\right)$ 8: $164.1\left(\mathrm{CO}_{\text {thread }}\right), 159.4\left(\mathrm{CO}_{\text {macrocycle }}\right), 153.1$, $136.9(\mathrm{C}), 130.9,129.2,128.0(\mathrm{C}), 56.5\left(\mathrm{CH}_{2}\right), 56.4\left(\mathrm{CH}_{2}\right), 44.4\left(\mathrm{CH}_{2}\right), 37.8(\mathrm{CH}), 37.3(\mathrm{CH}), 31.8$, 30.9, 26.0, 25.6. HRMS (ESI) calcd. for $\mathrm{C}_{60} \mathrm{H}_{79} \mathrm{~N}_{10} \mathrm{O}_{6}[\mathrm{M}+\mathrm{H}]^{+}$1035.6184, found 1035.6189 .

\subsection{Chemical Exchange of [2]Rotaxanes 3 and [2H]-3}

\subsubsection{Reduction Protocol}

To a solution of the [2] rotaxane $3(55 \mathrm{mg}, 0.05 \mathrm{mmol})$ in chloroform $(5 \mathrm{~mL})$ was added hydrazine monohydrate $(5 \mu \mathrm{L})$ in one go. The orange solution was transformed to a colorless solution in less than 5-10 $\mathrm{min}$. The reaction mixture was dried with a high vacuum pump to afford the [2]rotaxane [2H]-3 (54 mg, $0.05 \mathrm{mmol})$ as a colorless solid.

\subsubsection{Oxidation Protocol}

To a solution of the [2]rotaxane $[2 \mathrm{H}]-3(39 \mathrm{mg}, 0.04 \mathrm{mmol})$ in dichloromethane $(5 \mathrm{~mL})$ were added pyridine $(4 \mu \mathrm{L})$ and $N$-bromosuccinimide $(7 \mathrm{mg}, 0.04 \mathrm{mmol})$. The resulting orange solution was stirred at $25^{\circ} \mathrm{C}$ for $30 \mathrm{~min}$. Then the reaction mixture was diluted with dichloromethane $(10 \mathrm{~mL})$ and sequentially washed with water $(25 \mathrm{~mL}), 5 \%$ aqueous solution of $\mathrm{Na}_{2} \mathrm{~S}_{2} \mathrm{O}_{3}(20 \mathrm{~mL})$ and saturated solution of $\mathrm{NaHCO}_{3}(2 \times 20 \mathrm{~mL})$. The organic phase was dried with $\mathrm{MgSO}_{4}$, and concentrated under reduced pressure to afford the [2]rotaxane $3(37 \mathrm{mg}, 0.04 \mathrm{mmol})$ as an orange solid.

\subsection{Synthesis of Rotaxane 4}

To a solution of the [2] rotaxane $3(15 \mathrm{mg}, 0.014 \mathrm{mmol})$ in chloroform $(0.5 \mathrm{~mL})$ was added $m$-CPBA (7.5 mg, 3 equiv.). The resulting solution was stirred at $25^{\circ} \mathrm{C}$ for $2 \mathrm{~h}$. Then the reaction mixture was diluted with chloroform $(5 \mathrm{~mL})$ and sequentially washed with a saturated solution of $\mathrm{NaHCO}_{3}$ $(2 \times 10 \mathrm{~mL})$ and brine $(10 \mathrm{~mL})$. The organic phase was dried with $\mathrm{MgSO}_{4}$, and concentrated under reduced pressure to afford the [2] rotaxane $4(12 \mathrm{mg}, 81 \%)$ as an orange solid. m.p. $>300{ }^{\circ} \mathrm{C}$. ${ }^{1} \mathrm{H}-\mathrm{NMR}$ $\left(400 \mathrm{MHz}, \mathrm{CDCl}_{3}\right) \delta: 8.97\left(\mathrm{~d}, J=1.0 \mathrm{~Hz}, 4 \mathrm{H}, \mathrm{H}_{\mathrm{B}}\right), 8.30\left(\mathrm{~s}, 2 \mathrm{H}, \mathrm{H}_{\mathrm{C}}\right), 7.14\left(\mathrm{~d}, J=6.3 \mathrm{~Hz}, 4 \mathrm{H}, \mathrm{NH}_{\mathrm{D}}\right)$, $7.05\left(\mathrm{~s}, 8 \mathrm{H}, \mathrm{H}_{\mathrm{F}}\right), 4.96\left(\mathrm{dd}, J=14.3 \mathrm{~Hz}, J=7.6 \mathrm{~Hz}, 4 \mathrm{H}, \mathrm{H}_{\mathrm{E}}{ }^{\prime}\right), 4.03(\mathrm{dd}, J=14.3 \mathrm{~Hz}, J=1.8 \mathrm{~Hz}, 4 \mathrm{H}$, $\left.\mathrm{H}_{\mathrm{E}}\right), 3.32-3.27\left(\mathrm{~m}, 8 \mathrm{H}, \mathrm{H}_{\mathrm{b}}\right), 1.85-1.55\left(\mathrm{~m}, 18 \mathrm{H}, \mathrm{H}_{\mathrm{Cy}}\right), 1.16-0.98\left(\mathrm{~m}, 20 \mathrm{H}, \mathrm{H}_{\mathrm{Cy}}\right), 0.71-0.65\left(\mathrm{~m}, 2 \mathrm{H}, \mathrm{H}_{\mathrm{Cy}}\right)$, 0.54-0.43 (m, 4H, $\left.\mathrm{H}_{\mathrm{Cy}}\right) .{ }^{13} \mathrm{C}-\mathrm{NMR}\left(100 \mathrm{MHz}, \mathrm{CDCl}_{3}\right) \delta: 161.6\left(\mathrm{CO}_{\text {thread }}\right), 159.4\left(\mathrm{CO}_{\text {macrocycle }}\right), 142.3$, $136.6(\mathrm{C}), 132.4,129.2,119.2(\mathrm{C}), 56.5\left(\mathrm{CH}_{2}\right), 56.3\left(\mathrm{CH}_{2}\right), 44.5\left(\mathrm{CH}_{2}\right), 37.7(\mathrm{CH}), 37.3(\mathrm{CH}), 31.8$, 31.1, 26.0, 25.9, 25.4. HRMS (ESI) calcd. for $\mathrm{C}_{60} \mathrm{H}_{79} \mathrm{~N}_{10} \mathrm{O}_{8}[\mathrm{M}+\mathrm{H}]^{+}$1067.6077, found 1067.6045.

\subsection{Synthesis of Rotaxane 5}

To a solution of the [2]rotaxane $3(10 \mathrm{mg}, 0.01 \mathrm{mmol})$ in chloroform $(0.5 \mathrm{~mL})$ was added trifluoroacetic acid $(2.2 \mu \mathrm{L}, 3$ equiv.). The resulting solution was stirred at room temperature for $1 \mathrm{~h}$. Then the solvent and excess of TFA were removed under vacuum, affording the [2]rotaxane 5 (11 mg, 93\%) as an brown solid. m.p. > $300{ }^{\circ} \mathrm{C} .{ }^{1} \mathrm{H}-\mathrm{NMR}\left(400 \mathrm{MHz}, \mathrm{CDCl}_{3}\right) \delta: 9.47(\mathrm{dd}, J=1.8 \mathrm{~Hz}, 4 \mathrm{H}$, $\left.\mathrm{H}_{\mathrm{B}}\right), 8.78\left(\mathrm{t}, J=1.8 \mathrm{~Hz}, 2 \mathrm{H}, \mathrm{H}_{\mathrm{C}}\right), 7.14\left(\mathrm{~d}, J=5.8 \mathrm{~Hz}, 4 \mathrm{H}, \mathrm{NH}_{\mathrm{D}}\right), 7.06\left(\mathrm{~s}, 8 \mathrm{H}, \mathrm{CH}_{\mathrm{F}}\right), 4.96(\mathrm{dd}, J=14.3 \mathrm{~Hz}$, $\left.J=7.4 \mathrm{~Hz}, 4 \mathrm{H}, \mathrm{H}_{\mathrm{E}}{ }^{\prime}\right), 4.08\left(\mathrm{dd}, J=14.2 \mathrm{~Hz}, J=2.0 \mathrm{~Hz}, 4 \mathrm{H}, \mathrm{H}_{\mathrm{E}}\right), 3.29-3.24\left(\mathrm{~m}, 8 \mathrm{H}, \mathrm{H}_{\mathrm{b}}\right), 1.85-1.47(\mathrm{~m}, 18 \mathrm{H}$, $\left.\mathrm{H}_{\mathrm{Cy}}\right), 1.42-0.88\left(\mathrm{~m}, 20 \mathrm{H}, \mathrm{H}_{\mathrm{Cy}}\right), 0.71-0.59\left(\mathrm{~m}, 2 \mathrm{H}, \mathrm{H}_{\mathrm{Cy}}\right), 0.47-0.32\left(\mathrm{~m}, 4 \mathrm{H}, \mathrm{H}_{\mathrm{Cy}}\right) .{ }^{19} \mathrm{~F}-\mathrm{NMR}(282 \mathrm{MHz}$, $\left.\mathrm{CDCl}_{3}\right) \delta: 75.87$.

\subsection{Synthesis of Rotaxane 6}

To a solution of the [2]rotaxane $3(15 \mathrm{mg}, 0.014 \mathrm{mmol})$ in acetonitrile $(0.5 \mathrm{~mL})$ was added allyl iodide ( $7.3 \mathrm{mg}, 3$ equiv.). The resulting solution was stirred at $70{ }^{\circ} \mathrm{C}$ for $48 \mathrm{~h}$. Then the solvent was removed under vacuum. The resulting residue was washed with $\mathrm{Et}_{2} \mathrm{O}$ and $\mathrm{CHCl}_{3}$ to afford the [2]rotaxane 6 (14 mg, 73\%) as an brown solid. m.p. > $300{ }^{\circ} \mathrm{C} .{ }^{1} \mathrm{H}-\mathrm{NMR}\left(300 \mathrm{MHz}, \mathrm{DMSO}-d_{6}\right) \delta: 9.67$ (d, 
$\left.J=1.3 \mathrm{~Hz}, 4 \mathrm{H}, \mathrm{H}_{\mathrm{B}}\right), 89.39\left(\mathrm{~s}, 2 \mathrm{H}, \mathrm{H}_{\mathrm{C}}\right), 8.87\left(\mathrm{t}, J=5.2 \mathrm{~Hz}, 4 \mathrm{H}, \mathrm{NH}_{\mathrm{D}}\right), 7.04\left(\mathrm{~s}, 8 \mathrm{H}, \mathrm{H}_{\mathrm{F}}\right), 6.24-6.11(\mathrm{~m}, 2 \mathrm{H}$, $\left.\mathrm{H}_{\mathrm{H}}\right), 5.66-5.42\left(\mathrm{~m}, 4 \mathrm{H}, \mathrm{H}_{\mathrm{G}+\mathrm{I}}\right), 4.45\left(\mathrm{~s}, 8 \mathrm{H}, \mathrm{CH}_{\mathrm{E}}\right), 3.23\left(\mathrm{~d}, J=6.8 \mathrm{~Hz}, 4 \mathrm{H}, \mathrm{CH}_{\mathrm{b}}\right), 3.07(\mathrm{~d}, J=7.2 \mathrm{~Hz}, 4 \mathrm{H}$, $\left.\mathrm{CH}_{\mathrm{b}^{\prime}}\right), 1.80-0.88\left(\mathrm{~m}, 38 \mathrm{H}, \mathrm{H}_{\mathrm{Cy}}\right), 0.71-0.62\left(\mathrm{~m}, 2 \mathrm{H}, \mathrm{H}_{\mathrm{Cy}}\right), 0.20-0.05\left(\mathrm{~m}, 4 \mathrm{H}, \mathrm{H}_{\mathrm{Cy}}\right) .{ }^{13} \mathrm{C}-\mathrm{NMR}(75 \mathrm{MHz}$, DMSO- $\left.d_{6}\right) \delta: 160.7$ (CO thread $), 158.5\left(\mathrm{CO}_{\text {macrocycle }}\right), 146.2,141.4(\mathrm{C}), 136.2,134.3,131.1(\mathrm{C}), 128.0,123.1$ $\left(\mathrm{CH}_{2}\right), 63.2\left(\mathrm{CH}_{2}\right), 54.4\left(\mathrm{CH}_{2}\right), 54.2\left(\mathrm{CH}_{2}\right), 43.6\left(\mathrm{CH}_{2}\right), 36.0\left(\mathrm{CH}_{2}\right), 30.5(\mathrm{CH}), 29.7(\mathrm{CH}), 25.9,25.8,25.7$, 25.3, 24.9. HRMS (ESI) calcd. for $\mathrm{C}_{66} \mathrm{H}_{87} \mathrm{~N}_{10} \mathrm{O}_{6}[\mathrm{M}+\mathrm{H}]^{+}$1115.6805, found 1115.6777.

\section{Conclusions}

In summary, we have described the assembly of two hydrogen-bonded [2]rotaxanes having a nitrogenated binding site and two pyridine rings in the macrocycle. A close inspection of their ${ }^{1} \mathrm{H} N M R$ spectra reveals a deep dissimilarity in the dynamic behavior of the cyclic component as consequence of the distinguishable affinity of the binding sites for the macrocycle and the non-covalent interactions between both interlocked components. The chemical interconversion between the azo and hydrazo forms of the [2]-rotaxane facilitated the development of a chemically-switchable interlocked system enable to exchange two different dynamic states as a function of the oxidation level of the binding site of one of the entwined components. Moreover, we functionalized the pyridine-based macrocycle by oxidation, protonation and alkylation reactions, finding a new chemical means of exchange the dynamics of such interlocked systems.

Supplementary Materials: Supplementary materials can be accessed online. ${ }^{1} \mathrm{H}-$ and ${ }^{13} \mathrm{C}$-spectral data and variable-temperature NMR experiments.

Acknowledgments: We gratefully acknowledge the MINECO (CTQ2014-56887-P), FEDER and Fundacion Seneca-CARM (Project 19240/PI/14) for the financial support. A.M.-C. thanks the Marie Curie COFUND and U-IMPACT programs (Grant Agreement 267143) and the MINECO (Contract No. FPDI-2013-16623) for the postdoctoral contracts.

Author Contributions: J.B. conceived and designed the experiments; J.S.M.-E., A.S.-S. and A.M.-C. performed the experiments; A.M.-C., M.A. and J.B. analyzed the data; A.M.-C. and J.B. wrote the paper. All authors commented on the completed manuscript.

Conflicts of Interest: The authors declare no conflict of interest.

\section{References}

1. Dietrich-Buchecker, C.; Sauvage, J. Interlocking of molecular threads: From the statistical approach to the templated synthesis catenands. Chem. Rev. 1987, 87, 795-810. [CrossRef]

2. Amabilino, D.B.; Stoddart, J.F. Interlocked and intertwined structures and superstructures. Chem. Rev. 1995, 95, 2725-2829. [CrossRef]

3. Beves, J.E.; Blight, B.A.; Campbell, C.J.; Leigh, D.A.; McBurney, R.T. Strategies and tactics for the metal-directed synthesis of rotaxanes, knots, catenanes, and higher order links. Angew. Chem. Int. Ed. 2011, 50, 9260-9327. [CrossRef] [PubMed]

4. Xue, M.; Yang, Y.; Chi, X.; Yan, X.; Huang, F. Development of Pseudorotaxanes and Rotaxanes: From Synthesis to Stimuli-Responsive Motions to Applications. Chem. Rev. 2015, 115, 7398-7501. [CrossRef] [PubMed]

5. Gil-Ramirez, G.; Leigh, D.A.; Stephens, J.A. Catenanes: Fifty years of molecular links. Angew. Chem. Int. Ed. 2015, 54, 6110-6150. [CrossRef] [PubMed]

6. Sauvage, J.-P. Transition metal-containing rotaxanes and catenanes in motions: Toward molecular machines and motors. Acc. Chem. Res. 1998, 31, 611-619. [CrossRef]

7. Balzani, V.; Credi, A.; Raymo, F.M.; Stoddart, J.F. Artificial Molecular Machines. Angew. Chem. Int. Ed. 2000, 39, 3348-3391. [CrossRef]

8. Kay, E.R.; Leigh, D.A.; Zerbetto, F. Synthetic molecular motors and mechanical machines. Angew. Chem. Int. Ed. 2007, 46, 72-191. [CrossRef] [PubMed]

9. Erbas-Cakmak, S.; Leigh, D.A.; McTernan, C.T.; Nussbaumer, A.L. Artificial molecular machines. Chem. Rev. 2015, 115, 10081-10206. [CrossRef] [PubMed] 
10. Sun, J.; Wu, Y.; Wang, Y.; Liu, Z.; Cheng, C.; Hartlieb, K.J.; Wasielewski, M.R.; Stoddart, J.F. An Electrochromic Tristable Molecular Switch. J. Am. Chem. Soc. 2015, 137, 13484-13487. [CrossRef] [PubMed]

11. Vukotic, N.; O’Keefe, C.A.; Zhu, K.; Harris, K.J.; To, C.; Schurko, R.W.; Loeb, S.J. Mechanically Interlocked Linkers inside Metal-Organic Frameworks: Effect of Ring Size on Rotational Dynamics. J. Am. Chem. Soc. 2015, 137, 9643-9651. [CrossRef] [PubMed]

12. Barendt, T.A.; Ferreira, L.; Marques, I.; Felix, V.; Beer, P.D. Anion- and solvent-induced rotary dynamics and sensing in a perylene diimide [3]catenane. J. Am. Chem. Soc. 2017. [CrossRef] [PubMed]

13. Berna, J.; Bottari, G.; Leigh, D.A.; Perez, E.M. Amide-based molecular shuttles (2001-2006). Pure Appl. Chem. 2007, 79, 39-54. [CrossRef]

14. Panman, M.R.; Bakker, B.H.; den Uyl, D.; Kay, E.R.; Leigh, D.A.; Buma, W.J.; Brouwer, A.M.; Geenevasen, J.A.J.; Woutersen, S. Water lubricates hydrogen-bonded molecular machines. Nat. Chem. 2013, 5, 929-934. [CrossRef] [PubMed]

15. Martinez-Cuezva, A.; Lopez-Leonardo, C.; Bautista, D.; Alajarin, M.; Berna, J. Stereocontrolled Synthesis of $\beta$-Lactams within [2]Rotaxanes: Showcasing the Chemical Consequences of the Mechanical Bond. J. Am. Chem. Soc. 2016, 138, 8726-8729. [CrossRef] [PubMed]

16. Bermudez, V.; Capron, N.; Gase, T.; Gatti, F.G.; Kajzar, F.; Leigh, D.A.; Zerbetto, F.; Zhang, S. Influencing Intramolecular Motion with an Alternating Electric Field. Nature 2000, 406, 608-611. [PubMed]

17. D'Souza, D.M.; Leigh, D.A.; Mottier, L.; Mullen, K.M.; Paolucci, F.; Teat, S.J.; Zhang, S. Nitrone [2]Rotaxanes: Simultaneous Chemical Protection and Electrochemical Activation of a Functional Group. J. Am. Chem. Soc. 2010, 132, 9465-9470. [CrossRef] [PubMed]

18. Arunkumar, E.; Forbes, C.C.; Noll, B.C.; Smith, B.D. Squaraine-Derived Rotaxanes: Sterically Protected Fluorescent Near-IR Dyes. J. Am. Chem. Soc. 2005, 127, 3288-3289. [CrossRef] [PubMed]

19. Gassensmith, J.J.; Baumes, J.M.; Smith, B.D. Discovery and early development of squaraine rotaxanes. Chem. Commun. 2009, 42, 6329-6338. [CrossRef] [PubMed]

20. Martinez-Cuezva, A.; Berna, J.; Orenes, R.-A.; Pastor, A.; Alajarin, M. Small-Molecule Recognition for Controlling Molecular Motion in Hydrogen-Bond-Assembled Rotaxanes. Angew. Chem. Int. Ed. 2014, 53, 6762-6767. [CrossRef] [PubMed]

21. Martinez-Cuezva, A.; Pastor, A.; Cioncoloni, G.; Orenes, R.-A.; Alajarin, M.; Symes, M.D.; Berna, J. Versatile control of the submolecular motion of di(acylamino)pyridine-based [2]rotaxanes. Chem. Sci. 2015, 6, 3087-3094. [CrossRef]

22. Martinez-Cuezva, A.; Carro-Guillen, F.; Pastor, A.; Marin-Luna, M.; Orenes, R.-A.; Alajarin, M.; Berna, J. Co-conformational Exchange Triggered by Molecular Recognition in a Di(acylamino)pyridine-Based Molecular Shuttle Containing Two Pyridine Rings at the Macrocycle. Chem. Phys. Chem. 2016, 17, 1920-1926. [CrossRef] [PubMed]

23. Tron, A.; Pianet, I.; Martinez-Cuezva, A.; Tucker, J.H.R.; Pisciottani, L.; Alajarin, M.; Berna, J.; McClenaghan, N.D. Remote Photoregulated Ring Gliding in a [2]Rotaxane via a Molecular Effector. Org. Lett. 2017, 19, 154-157. [CrossRef] [PubMed]

24. Langton, M.J.; Robinson, S.W.; Marques, I.; Félix, V.; Beer, P.D. Halogen bonding in water results in enhanced anion recognition in acyclic and rotaxane hosts. Nat. Chem. 2014, 6, 1039-1043. [CrossRef] [PubMed]

25. Spence, G.T.; Beer, P.D. Expanding the Scope of the Anion Templated Synthesis of Interlocked Structures. Acc. Chem. Res. 2013, 46, 571-586. [CrossRef] [PubMed]

26. Berna, J.; Alajarin, M.; Orenes, R.-A. Azodicarboxamides as Template Binding Motifs for the Building of Hydrogen-Bonded Molecular Shuttles. J. Am. Chem. Soc. 2010, 132, 10741-10747. [CrossRef] [PubMed]

27. Berna, J.; Alajarin, M.; Marin-Rodriguez, C.; Franco-Pujante, C. Redox divergent conversion of a [2]rotaxane into two distinct degenerate partners with different shuttling dynamics. Chem. Sci. 2012, 3, 2314-2320. [CrossRef]

28. Berna, J.; Franco-Pujante, C.; Alajarin, M. Competitive binding for triggering a fluorescence response in a hydrazodicarboxamide-based [2]rotaxane. Org. Biomol. Chem. 2014, 12, 474-478. [CrossRef] [PubMed]

29. Berna, J.; Alajarin, M.; Martinez-Espin, J.S.; Buriol, L.; Martins, M.A.P.; Orenes, R.-A. Dampened circumrotation by $\mathrm{CH} \cdots \pi$ interactions in hydrogen bonded [2]rotaxanes. Chem. Commun. 2012, 48, 5677-5679. [CrossRef] [PubMed]

30. Chang, S.-Y.; Kim, H.S.; Chang, K.-J.; Jeong, K.-S. Efficient Modulation of Hydrogen-Bonding Interactions by Remote Substituents. Org. Lett. 2004, 6, 181-184. [CrossRef] [PubMed] 
31. Farràs, P.; Escudero-Adán, E.C.; Viñas, C.; Teixidor, F. Controlling the Pirouetting Motion in Rotaxanes by Counterion Exchange. Inorg. Chem. 2014, 53, 8654-8661. [CrossRef] [PubMed]

32. Reynolds, C.H.; Hormann, R.E. Theoretical Study of the Structure and Rotational Flexibility of Diacylhydrazines: Implications for the Structure of Nonsteroidal Ecdysone Agonists and Azapeptides. J. Am. Chem. Soc. 1996, 118, 9395-9401. [CrossRef]

33. Leigh, D.A.; Murphy, A.; Smart, J.P.; Slawin, A.M.Z. Glycylglycine Rotaxanes-The Hydrogen Bond Directed Assembly of Synthetic Peptide Rotaxanes. Angew. Chem. Int. Ed. Engl. 1997, 36, 728-732. [CrossRef]

34. Gatti, F.G.; Leigh, D.A.; Nepogodiev, S.A.; Slawin, A.M.Z.; Teat, S.J.; Wong, J.K.Y. Stiff, and sticky in the right places: The dramatic influence of preorganizing guest binding sites on the hydrogen bond-directed assembly of rotaxanes. J. Am. Chem. Soc. 2001, 123, 5983-5989. [CrossRef] [PubMed]

35. Gatti, F.G.; León, S.; Wong, J.K.Y.; Bottari, G.; Altieri, A.; Morales, M.A.F.; Teat, S.J.; Frochot, C.; Leigh, D.A.; Brouwer, A.M.; et al. Photoisomerization of a rotaxane hydrogen bonding template: Light-induced acceleration of a large amplitude rotational motion. Proc. Natl. Acad. Sci. USA 2003, 100, 10-14. [CrossRef] [PubMed]

36. Altieri, A.; Gatti, F.G.; Kay, E.R.; Leigh, D.A.; Martel, D.; Paolucci, F.; Slawin, A.M.Z.; Wong, J.K.Y. Electrochemically switchable hydrogen-bonded molecular shuttles. J. Am. Chem. Soc. 2003, 125, 8644-8654. [CrossRef] [PubMed]

37. Murgu, I.; Baumes, J.M.; Eberhard, J.; Gassensmith, J.J.; Arunkumar, E.; Smith, B.D. Macrocycle breathing in [2]rotaxanes with tetralactam macrocycles. J. Org. Chem. 2011, 76, 688-691. [CrossRef] [PubMed]

38. Nishio, M.; Umezawa, Y.; Fantini, J.; Weiss, M.S.; Chakrabarti, P. CH- $\pi$ hydrogen bonds in biological macromolecules. Phys. Chem. Chem. Phys. 2014, 16, 12648-12683. [CrossRef] [PubMed]

39. Zhang, Z.; Luo, Y.; Chen, J.; Dong, S.; Yu, Y.; Ma, Z.; Huang, F. Formation of Linear Supramolecular Polymers That Is Driven by $\mathrm{CH} \cdots \pi$ Interactions in Solution and in the Solid State. Angew. Chem. Int. Ed. 2011, 50, 1397-1401. [CrossRef] [PubMed]

Sample Availability: Samples of the compounds are not available from the authors.

(C) 2017 by the authors. Licensee MDPI, Basel, Switzerland. This article is an open access article distributed under the terms and conditions of the Creative Commons Attribution (CC BY) license (http://creativecommons.org/licenses/by/4.0/). 